\title{
Optical properties of long-range transported Saharan dust over Barbados as measured by dual-wavelength depolarization Raman lidar measurements
}

\author{
S. Groß ${ }^{1}$, V. Freudenthaler ${ }^{2}$, K. Schepanski ${ }^{4}$, C. Toledano ${ }^{3}$, A. Schäfler ${ }^{1}$, A. Ansmann ${ }^{4}$, and B. Weinzierl ${ }^{1,2}$ \\ ${ }^{1}$ Deutsches Zentrum für Luft- und Raumfahrt (DLR), Institut für Physik der Atmosphäre, Oberpfaffenhofen, Germany \\ ${ }^{2}$ Ludwig-Maximilians-Universität, Meteorologisches Institut, München, Germany \\ ${ }^{3}$ Universitat de Valladolid, Valladolid, Spain \\ ${ }^{4}$ Leibniz-Institut für Troposphärenforschung (TROPOS), Leipzig, Germany
}

Correspondence to: S. Groß (silke.gross@dlr.de)

Received: 17 June 2015 - Published in Atmos. Chem. Phys. Discuss.: 15 July 2015

Revised: 15 September 2015 - Accepted: 22 September 2015 - Published: 6 October 2015

\begin{abstract}
Dual-wavelength Raman and depolarization lidar observations were performed during the Saharan Aerosol Long-range Transport and Aerosol-Cloud interaction Experiment in Barbados in June and July 2013 to characterize the optical properties and vertical distribution of long-range transported Saharan dust after transport across the Atlantic Ocean. Four major dust events were studied during the measurements from 15 June to 13 July 2013 with aerosol optical depths at $532 \mathrm{~nm}$ of up to 0.6 . The vertical aerosol distribution was characterized by a three-layer structure consisting of the boundary layer, the entrainment or mixing layer and the pure Saharan dust layer. The upper boundary of the pure dust layer reached up to $4.5 \mathrm{~km}$ in height. The contribution of the pure dust layer was about half of the total aerosol optical depth at $532 \mathrm{~nm}$. The total dust contribution was about $50-70 \%$ of the total aerosol optical depth at $532 \mathrm{~nm}$. The lidar ratio within the pure dust layer was found to be wavelength independent with mean values of $53 \pm 5 \mathrm{sr}$ at $355 \mathrm{~nm}$ and $56 \pm 7 \mathrm{sr}$ at $532 \mathrm{~nm}$. For the particle linear depolarization ratio, wavelength-independent mean values of $0.26 \pm 0.03$ at $355 \mathrm{~nm}$ and $0.27 \pm 0.01$ at $532 \mathrm{~nm}$ have been found.
\end{abstract}

\section{Introduction}

Aerosol particles play a key role in the Earth's climate system and affect the Earth's radiation budget in two different ways: directly by interacting with solar and terrestrial radiation (scattering and absorption) and indirectly by acting as cloud condensation nuclei and thereby influencing the clouds' microphysical and optical properties and the clouds' lifetime. Until now the impact of aerosols on the global climate system has not been fully understood (Forster et al., 2007; Penner et al., 2011; Boucher et al., 2013). One main reason is the strong variability of aerosols. The sign and the magnitude of the radiative forcing crucially depends on the vertical distribution of aerosols, their microphysical properties and chemical composition, the reflectance of the underlying surface and the occurrence and amount of clouds (Forster et al., 2007). However, knowledge of the temporal and vertical aerosol distribution on the global scale is limited (Penner et al., 2001; IPCC, 2013). Additionally, significant sources of uncertainty result from deficits of satellite-based measurements in the determination of global mean aerosol optical depth (AOD) (Su et al., 2013) and from the insufficient knowledge of the impact of mixing, aging processes and transport on the aerosol optical and microphysical properties.

Advanced lidar systems like Raman lidar systems (Ansmann et al., 1990, 1992) or high spectral resolution lidar (HSRL) systems (Shipley et al., 1983; Shimizu et al., 1983; Piironen and Eloranta, 1994) with polarization sensitive channels (Sassen et al., 1989; Freudenthaler et al., 2009) provide information about the optical properties of aerosol layers. Spaceborne lidar measurements are an excellent tool to examine the global vertical distribution of aerosols. The Cloud-Aerosol Lidar with Orthogonal Polarization 
(CALIOP) on board the Cloud-Aerosol Lidar and Infrared Pathfinder Satellite Observations (CALIPSO) is an elastic backscatter lidar system (Winker et al., 2009) and has only limited capability to distinguish different types of aerosols (Omar et al., 2009). In contrast, with the Cloud-Aerosol Transport System (CATS) currently flying on board the International Space Station and the future ESA satellite mission EarthCARE polarization sensitive HSRL systems are deployed which have the potential to classify different aerosol types (Burton et al., 2012; Groß et al., 2013, 2015). However, current classification schemes for EarthCARE lidar measurements are mainly based on measurements of pure and fresh aerosol types (Groß et al., 2011a, 2014; Illingworth et al., 2015). However, as the optical properties are related to the microphysical properties like particle size, particle shape and chemical composition (Gasteiger et al., 2011b, a), aerosol aging, mixing and modification during transport can have an impact on the lidar-derived optical properties as well as on their wavelength dependence. For example, for measurements of the lidar ratio over Greece, Amiridis et al. (2009) found that both the value and the wavelength dependence of the lidar ratio of biomass burning aerosols may change with aerosol lifetime. Thus, possible changes of the lidar-derived optical properties have to be investigated and considered for proper aerosol classification.

Mineral dust is a major component of the atmospheric aerosol (Haywood and Boucher, 2010; Forster et al., 2007) with the Saharan desert being the most important source of mineral dust (Goudie and Middleton, 2001; Washington et al., 2003; Shao et al., 2011). Once lifted in the air, mineral dust can be transported over thousands of kilometers (Goudie and Middleton, 2001; Liu et al., 2008) and exposed to the effects of aging and mixing. These effects change the optical, microphysical and cloud condensation properties. Coatings on mineral dust particles and mixing with other aerosols change the optical properties (Nousiainen, 2009; Redmond et al., 2010) and thus alter their radiative impact (Bauer et al., 2007). For example, biomass burning aerosols and mineral dust may become internally mixed when aging together (Hand et al., 2010) and thus change their size distribution, optical properties, hygroscopicity and ability to act as cloud condensation nuclei. From measurements close to the dust source regions in comparisons to measurements in dust plumes over Cape Verde, Weinzierl et al. (2011) found an indication of sedimentation of large particles in Saharan dust plumes during transport although sedimentation of large super-micron dust particles was less pronounced than expected from Stokes gravitational settling. Yang et al. (2013) assume a shape-induced particle sedimentation from measurements of transported dust with the space-based lidar system onboard the CALIOP satellite mission (Winker et al., 2009). Wiegner et al. (2011) found an increase of the mean particle linear depolarization ratio at $355 \mathrm{~nm}$ of an aged Saharan dust plume over Central Europe compared to values measured in fresh Saharan dust plumes (Freudenthaler et al.,
2009; Groß et al., 2011b). Until now the mechanism and magnitude of dust aging have been unknown in addition to whether and how they influence the optical properties of dust.

In this work we present dual-wavelength Raman and depolarization lidar measurements of long-range transported Saharan dust over Barbados. Our study includes a general investigation of aerosol layering and optical depth during our measurement period as well as the characterization of the Saharan dust layer and marine boundary layer by means of the lidar ratio and the particle linear depolarization ratio. These observations are crucial to investigate possible age-induced changes in the intensive lidar optical properties necessary for lidar-based aerosol classification schemes. The measurements were performed during the Saharan Aerosol Long-range Transport and Aerosol-Cloud interaction Experiment (SALTRACE, http://www.pa.op.dlr.de/ saltrace/index.html) closure experiment. A general description of the SALTRACE campaign, our lidar measurements and data analysis is given is Sect. 2 . The results are presented in Sect. 3 and discussed in Sect. 4. Section 5 summarizes this work.

\section{Measurements and instrumentation}

\subsection{SALTRACE}

In June and July 2013 SALTRACE took place. SALTRACE was designed as a closure experiment combining groundbased lidar, in situ and sun-photometer instruments with airborne aerosol and wind lidar measurements onboard the research aircraft Falcon of the Deutsches Zentrum für Luftund Raumfahrt (DLR), satellite observations and model simulations. The main ground site during SALTRACE was on Barbados, where extensive lidar measurements were performed. Barbados is an optimal location to characterize long-range transported dust after transport across the Atlantic Ocean. In addition, the 50-year Barbados dust record (Prospero et al., 1970) provides long-term information on year-to-year variability of trans-Atlantic dust transport to the Caribbean. The SALTRACE project continues the work started with the SAMUM-1 and SAMUM-2 (Ansmann et al., 2011) which aimed to characterize Saharan mineral dust in the source regions and at different stages of dust lifetime. During SALTRACE, particular focus was drawn on aerosol aging and mixing and on aerosol removal processes. Therefore the physical, chemical and optical properties of the longrange transported Saharan dust layers were characterized indepth to study the impact of long-range transported dust on the Earth's radiation budget, clouds and precipitation. During SALTRACE, ground-based measurements in Barbados were performed at two main locations: ground-based in situ measurements were made at the very eastern edge of the island at Ragged Point, whereas the lidar measurements were carried out at the Caribbean Institute of Meteorology and 
Hydrology (CIMH) in the southwestern side of Barbados $\left(13.14^{\circ} \mathrm{N}, 59.62^{\circ} \mathrm{W}\right)$. Sun-photometer measurements were performed at both measurement sites. For this study we use the AERONET CIMEL (Holben et al., 1998) measurements "Barbados_SALTRACE" performed at CIMH. SALTRACE measurements were carried out between 10 June and 15 July with the main closure experiments taking place between 20 June and 12 July 2013.

\subsection{POLIS lidar system}

In this work we present measurements of the small portable Raman and depolarization lidar system POLIS of the Meteorological Institute (MIM) of the Ludwig-MaximiliansUniversität München. POLIS is a six-channel lidar system measuring the $\mathrm{N}_{2}$ Raman shifted wavelengths at 387 and $607 \mathrm{~nm}$ and the elastic backscattered signals (cross- and parallel-polarized) at 355 and $532 \mathrm{~nm}$ with high accuracy (Freudenthaler et al., 2015). Thus profiles of the particle extinction coefficient $\alpha_{\mathrm{p}}$ and backscatter coefficient $\beta_{\mathrm{p}}$, of the lidar ratio $S_{\mathrm{p}}$, and of the volume and particle linear depolarization ratio $\delta_{\mathrm{v}}$ and $\delta_{\mathrm{p}}$ at 355 and $532 \mathrm{~nm}$ can be retrieved. The full overlap of POLIS is at about 200 to $250 \mathrm{~m}$ depending on system settings. The range resolution of the raw data is $3.75 \mathrm{~m}$; the temporal resolution is $5-10 \mathrm{~s}$ depending on atmospheric conditions. The repetition rate of the frequency doubled and tripled Nd:YAG laser is $10 \mathrm{~Hz}$ with a pulse energy of $50 \mathrm{~mJ}$ at $355 \mathrm{~nm}$ and $27 \mathrm{~mJ}$ at $532 \mathrm{~nm}$.

\subsection{Data analysis}

The particle extinction coefficient $\alpha_{\mathrm{p}}$ is retrieved from the Raman signals at 387 and $607 \mathrm{~nm}$ (Ansmann et al., 1990), the particle backscatter coefficient $\beta_{\mathrm{p}}$ is derived from combined Raman and elastically backscattered lidar returns at $355 / 387$ and 532/607 nm (Ansmann et al., 1992). The height-dependent lidar ratio $S_{\mathrm{p}}=\alpha_{\mathrm{p}} / \beta_{\mathrm{p}}$ can be derived from the ratio of both properties. Due to the low signal-to-noise ratio of the Raman channels during daytime, these measurements were restricted to nighttime only. Furthermore, typical temporal averaging of $1 \mathrm{~h}$ is necessary for analyzing $\alpha_{\mathrm{p}}$ and $S_{\mathrm{p}}$ to achieve a sufficient signal-to-noise ratio. The temporal stability of the atmosphere within this time period has been validated by assessing the temporal evolution of the rangecorrected signal $\operatorname{Pr}^{2}$ over the whole smoothing period. A typical vertical smoothing of $\approx 940 \mathrm{~m}$ (250 rangebins) is applied to further increase the signal-to-noise ratio. The errors of the retrieved optical properties are calculated according to Groß et al. (2011c).

From the co- and cross-polarized elastically backscattered signals, the volume linear depolarization ratio $\delta_{\mathrm{v}}$ and the particle linear depolarization ratio $\delta_{\mathrm{p}}$ (Biele et al., 2000; Freudenthaler et al., 2009) are derived. The relative calibration factor of both polarization channels was determined with the $\pm 45^{\circ}$ calibration method (Freudenthaler et al., 2009) by

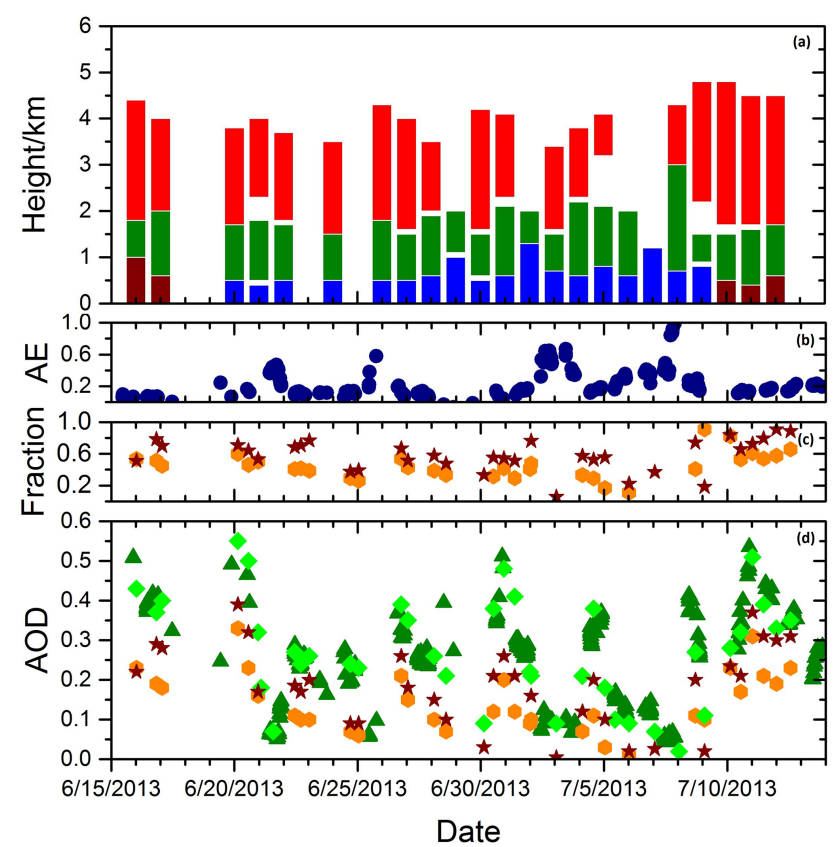

Figure 1. Time series of (a) aerosol layering during SALTRACE derived from POLIS lidar measurements during the evening measurement sessions (red indicates Saharan dust dominated aerosol layers, green indicates intermediate or mixed aerosol layers, blue indicates marine dominated aerosol layers and brown indicates mixtures of Saharan dust and marine aerosols); (b) Ångström exponents between 440 and $870 \mathrm{~nm}$ (blue dots) from CIMEL sun-photometer measurements; (c) the fraction of pure dust optical depth (orange) and total dust optical depth (brown stars) to the total aerosol optical depth (AOD); (d) AOD at $500 \mathrm{~nm}$ derived from CIMEL sunphotometer measurements (dark green) and at $532 \mathrm{~nm}$ derived from POLIS lidar measurements (light green) and optical depth of the pure dust layer (orange) and of the whole dust contribution in the atmospheric column (brown stars) at $532 \mathrm{~nm}$ derived from POLIS lidar measurement.

manually rotating the receiver optics behind the telescope. Although the signal-to-noise ratio of the elastic channels is much better than for the Raman channels, the same temporal average was used for the analysis of the nighttime Raman and depolarization measurements to get comparable results. The vertical average of the elastic signals is typically $\approx 550 \mathrm{~m}$ (150 range bins); otherwise the vertical smoothing length is specified in the text. Details of the depolarization calibration and system performance can be found in Freudenthaler et al. $(2009,2015)$. The error calculation of $\delta_{\mathrm{v}}$ and $\delta_{\mathrm{p}}$ was done analogue to Freudenthaler et al. (2009).

To determine the dust contribution within the boundary layer and the intermediate layer, we determined the profile of the dust backscatter coefficient by applying a procedure based on the work of Shimizu et al. (2004) and described by Tesche et al. (2009a) and Groß et al. (2011a), assuming a two-type mixture of dust and marine aerosols (based on coordinated in situ measurements). The linear depolarization 
ratios used as input for the aerosol type separation are set to $\delta_{\mathrm{d}}=0.30$ at $532 \mathrm{~nm}$ for dust and $\delta_{\mathrm{nd}}=0.02$ for marine aerosols (relative humidity $\geq 40 \%$ ) according to the findings for pure Saharan dust and marine aerosols (Freudenthaler et al., 2009; Groß et al., 2011b). The dust extinction coefficient is derived following the equation $\alpha_{\mathrm{d}}=\beta_{\mathrm{d}} \cdot S_{\mathrm{d}}$. The lidar ratio of dust $\left(S_{\mathrm{d}}=55 \mathrm{sr}\right)$ is taken from Tesche et al. (2009b) and is in good agreement with the mean $S_{\mathrm{p}}$ values we find for long-range transported Saharan dust during SALTRACE.

\subsection{Dust source regions and transport}

To identify dust source regions and transport way and time, we use a combination of back-trajectory calculation and satellite observations. The trajectories were calculated with the Hybrid Single Particle Lagrangian Integrated Trajectory (HYSPLIT) model (Draxler and Rolph, 2012) and the NCEP Global Data Assimilation System (GDAS) meteorological data. Start time and height of the trajectories were chosen according to the analyzed lidar measurement time periods and the height ranges of the presumed dust layer. The duration of all backward trajectories is $312 \mathrm{~h}$. Different dust source activity over North Africa and thus different source regions contributing to the dust plume observed in Barbados are identified from infrared dust index images calculated from Meteosat Second Generation (MSG) Spinning Enhanced Visible and Infrared Imager (SEVIRI) observations. As described in detail in Schepanski et al. (2007), active dust sources are identified and recorded on a $1^{\circ} \times 1^{\circ}$ map covering Africa north of $10^{\circ} \mathrm{N}$.

\section{Results}

\subsection{General overview}

During SALTRACE we observed a sequence of dust events with Saharan air masses being transported with easterly winds over the Atlantic to Barbados. The dust episodes often lasted for several days and provided, apart from shallow cumulus clouds, optimal measurement conditions in the dry and aerosol rich air. The dust events were interrupted by wet periods with strong convective activity and precipitation. Here we focus on the analysis of four major dust events.

The AOD at 500 and $532 \mathrm{~nm}$ during these major dust events reached values of up to 0.55 . The corresponding Ångström Exponent between 440 and $870 \mathrm{~nm}$ showed very low values of 0.2 and lower. The overall aerosol situation was characterized by a three-layer structure (Fig. 1). The optical properties of the boundary layer (up to 0.5 to $1.0 \mathrm{~nm}$ ) were mostly dominated by marine aerosols except during the first and last measurement days. At heights from about 1.0 to $2.0 \mathrm{~km}$ the aerosol layer was composed of a mixture of predominantly dust and marine aerosols. This layer showed high variability with respect to aerosol load and mixture. During SALTRACE almost all cloud processes in the lower tropo-
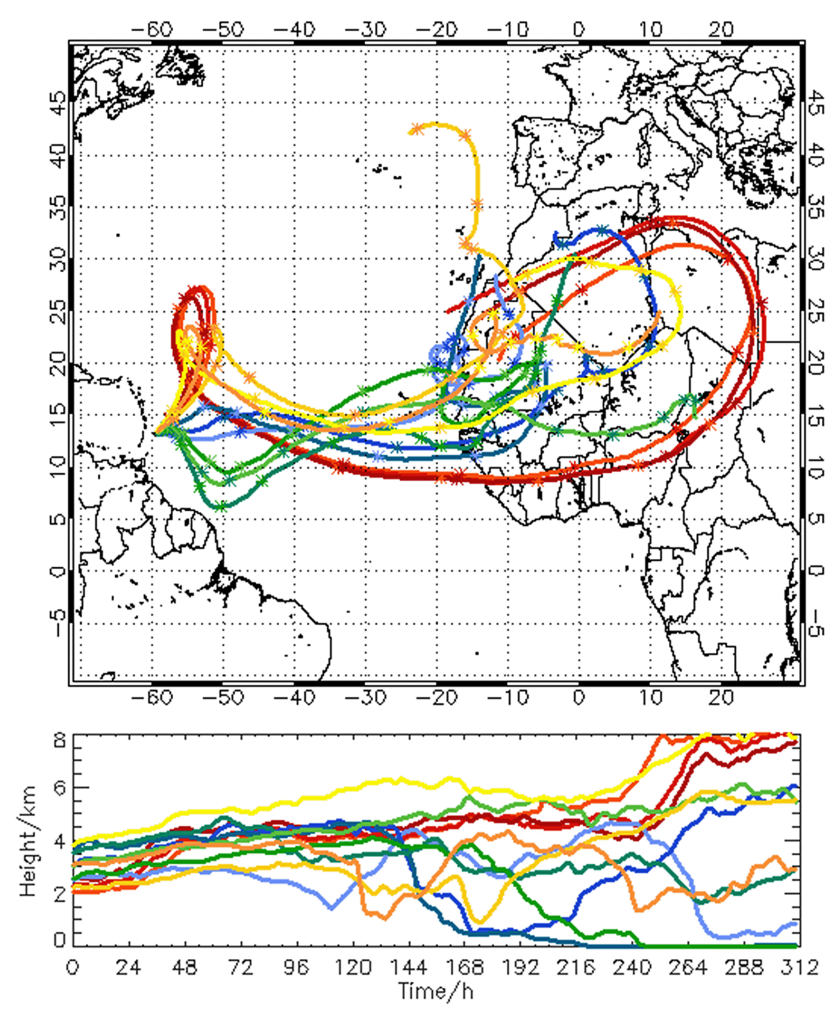

Figure 2. Shown are $312 \mathrm{~h}$ backward trajectories calculated with the Hybrid Single Particle Lagrangian Integrated Trajectory (HYSPLIT) model (Draxler and Rolph, 2012) and GDAS meteorological data for the pure dust layers on 20 June 2013, 23:00 UTC (red), 27 June 2013, 01:00 UTC (blue), 1 July 2013, 08:00 UTC (green), and 11 July, 23:00 UTC (yellow). The stars along the trajectories indicate $24 \mathrm{~h}$ time steps. The height range of the pure dust layers is indicated in Table 1.

sphere took place within this layer. Above this intermediate layer a Saharan dust layer was present almost permanently during our measurement period, except on 8 and 9 July when tropical storm "Chantal" dominated the weather situation. During the main Saharan dust events this uppermost dust layer showed AOD values of about 0.2 at $532 \mathrm{~nm}$; in some cases the AOD at $532 \mathrm{~nm}$ even reached values of more than 0.3 . The contribution of this pure Saharan dust layer to the total AOD at $532 \mathrm{~nm}$ usually ranged between 30 and $60 \%$, in some cases up to $80 \%$. The total contribution of Saharan dust to the total AOD at $532 \mathrm{~nm}$ was $50-80 \%$, except during tropical storm Chantal when the Saharan dust contribution to the total AOD at $532 \mathrm{~nm}$ was only $20 \%$. An overview over the vertical layering and the AOD is given in Fig. 1.

\subsection{Case studies}

We present four case studies which are representative of the four dust events that occurred during the core period of SALTRACE. The date and time of the chosen case studies are 20 June (23:00-24:00 UTC), 27 June (00:00- 


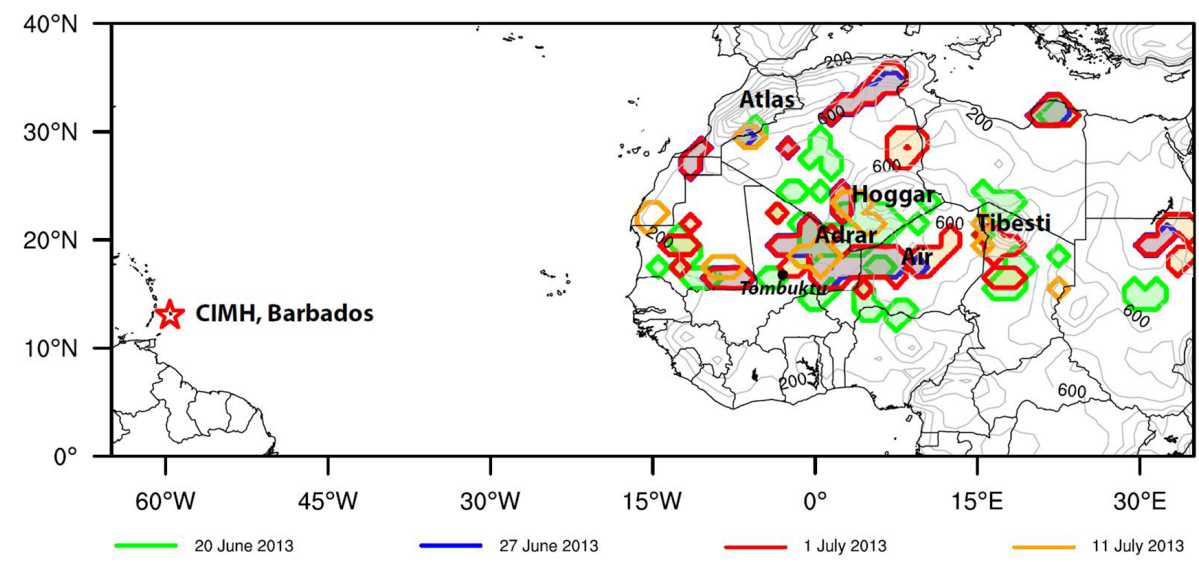

Figure 3. Active dust sources relevant for the four investigated case studies. The colors indicate which source region contributed to which dust event observed over Barbados.

02:00 UTC), 1 July (07:00-09:00 UTC) and 11 July 2013 (23:00-24:00 UTC). One main topic of our analysis is to investigate whether the different dust events show a variability in the retrieved optical properties. Figure 2 shows a back-trajectory analysis for the four selected case studies. All trajectories show an advection from easterly directions and source regions located inside the Sahara region. However, the specific flow patterns of the air masses of the different events are quite different as well as possible source regions within the Saharan desert.

For the four case studies (20 June, 27 June, 1 July, 11 July 2013), different dust source regions are found to be active (Fig. 3). A brief overview of the dust-contributing source regions and the meteorological regime resulting in dust uplift will be given in the following. HYSPLIT back trajectories are analyzed to identify the dates on which the Saharan air mass observed over Barbados where likely over dust source regions over North Africa. For the first two cases (20 and 27 June), dust source activation over North Africa was dominated by the Harmattan flow (a dry and dusty trade wind over West Africa). The latter two July cases (1 and 11 July) show an increase in deep convective activity and haboobs (heavy dust storm) become a more frequent dust uplift mechanism compared to the June cases.

\subsubsection{June 2013, 23:30-24:00 UTC}

Already during the first measurement period of the SALTRACE campaign were we able to observe a strong Saharan dust event with total AOD of up to 0.55. Dust sources contributing to the dusty air mass reaching Barbados on 20 June 2013 were active during 11 to 13 June 2013. On 11 June 2013, strong Harmattan winds and embedded nocturnal low-level jet (LLJ) forced dust uplift over the Adrar and southeastern Hoggar region (NE Mali and SW Algeria). Entrained into the northeasterly Harmattan flow, dusty air is transported towards the tropical North Atlantic. On
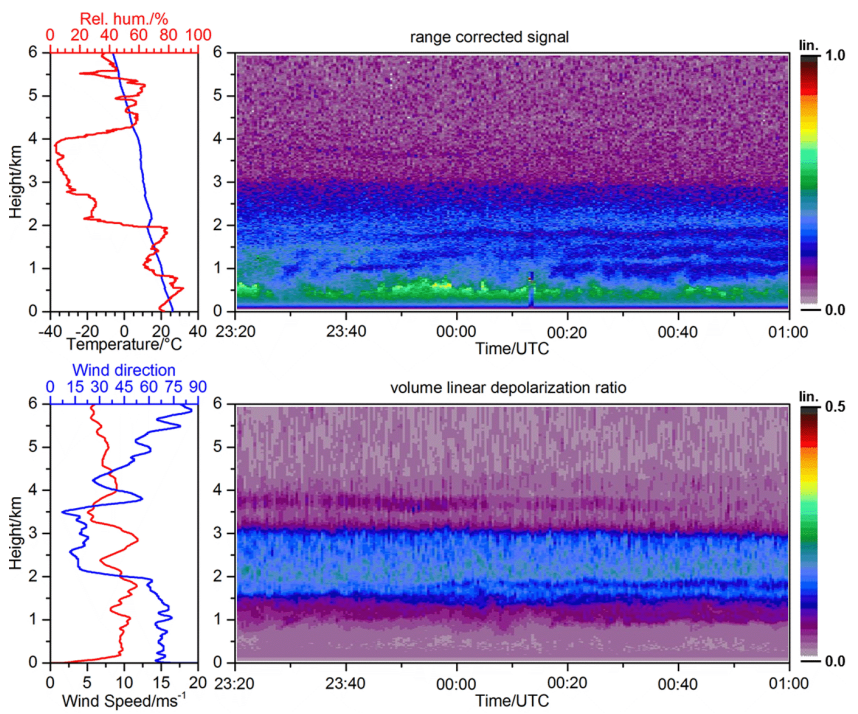

Figure 4. Radiosonde measurements of temperature and relative humidity (upper left panel) and of wind speed and wind direction (lower left panel) and lidar measurements of the range-corrected signal (upper right panel) and of the volume linear depolarization ratio (lower right panel) at $532 \mathrm{~nm}$ between 20 June 2013, 23:00 UTC, and 21 June 2013, 01:00 UTC. The radiosonde was launched on 21 June at 01:54 UTC.

12 June 2013, dust emitted by strong Harmattan winds from the Niger flood plains south of Timbuktu (Mali) were uptaken by an air mass crossing the Atlantic and reaching Barbados on 20 June 2013.

Figure 4 gives an overview of the measurement situation in the night from 20 to 21 June 2013 when the Saharan dust layer slowly faded away. The Saharan dust layer can be clearly identified by enhanced $\delta_{\mathrm{v}}$ of about 0.15 in heights from 1.5 to $3 \mathrm{~km}$. A clear signature to distinguish the dust layer from the mixing layer at about $0.8-1.5 \mathrm{~km}$ with rather similar values of the range-corrected signal but lower 


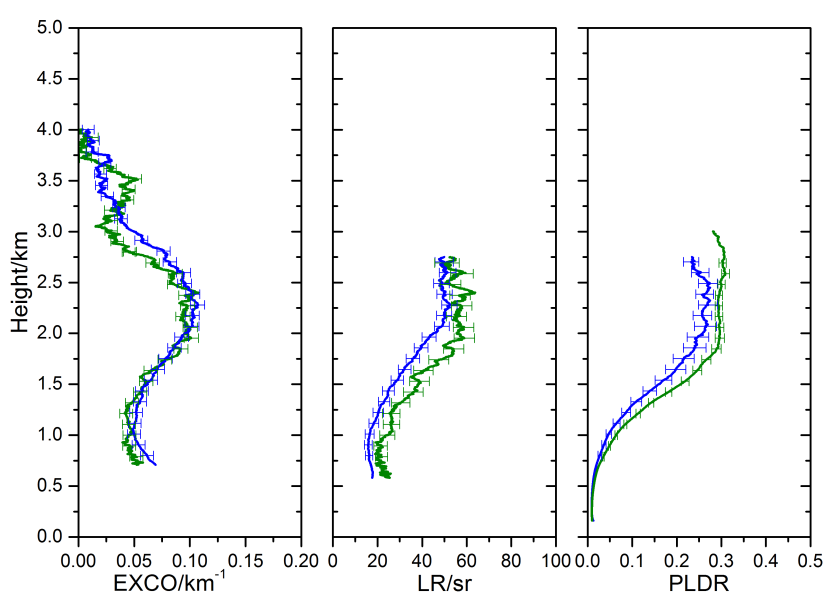

Figure 5. Profiles of the particle extinction coefficient (EXCO), the lidar ratio (LR) and of the particle linear depolarization ratio (PLDR) of the pure dust layer at $355 \mathrm{~nm}$ (blue) and $532 \mathrm{~nm}$ (green) on 20 June 2013, 23:30-24:00 UTC. The error bars indicate the systematic errors.

$\delta_{\mathrm{v}}$ values. In the lowermost $0.8 \mathrm{~km}$ the range-corrected signal shows high values with low $\delta_{\mathrm{v}}$, which is an indication for a marine-dominated boundary layer. At the height level of the Saharan Air Layer (SAL), the relative humidity is low (notice that lidar measurements and radiosonde measurements have an offset of about $2 \mathrm{~h}$ in this case study) and the air masses were transported from mainly northeasterly directions. In the lowermost height level the relative humidity shows values between 60 and $80 \%$. For the analysis of the vertical distribution of the extinction coefficient, the lidar ratio and the particle linear depolarization ratio (Fig. 6) we use a time period between 23:30 and 24:00 UTC with very homogeneous conditions. Increased values of $\alpha_{\mathrm{p}}$ are found up to $4 \mathrm{~km}$, but the highest $\alpha_{\mathrm{p}}$ values are found between 1.5 and $3.0 \mathrm{~km}$ with $\max . \alpha_{\mathrm{p}}$ of about $0.12 \mathrm{~km}^{-1}$. Mean $S_{\mathrm{p}}$ values in the dust layer are $56 \pm 5 \mathrm{sr}$ at $532 \mathrm{~nm}$ and $50 \pm 4 \mathrm{sr}$ at $355 \mathrm{~nm}$. In the marine boundary layer mean $S_{\mathrm{p}}$ values of $21 \pm 3 \mathrm{sr}$ at $532 \mathrm{~nm}$ and $17 \pm 2 \mathrm{sr}$ at $355 \mathrm{~nm}$ are found with corresponding wavelengthindependent mean $\delta_{\mathrm{p}}$ values of $\approx 0.02$. In the dust layer, $\delta_{\mathrm{p}}$ shows a slight wavelength dependence with mean values of 0.3 at $532 \mathrm{~nm}$ and 0.26 at $355 \mathrm{~nm}$.

\subsubsection{June 2013, 00:00-02:00 UTC}

Air masses being over the North African continent at boundary layer heights (up to $3-5 \mathrm{~km}$ ) and thus able to uptake dust during 20 to 22 June 2013 are likely to contribute to the dust layer observed over Barbados on 27 June 2013. On 20 June, dust source embedded in desert valleys scattered over the three mountain regions Hoggar, Aïr and Adrar were activated during the morning hours by nocturnal LLJs embedded in the Harmattan flow. The dusty air mass slowly propagated westward. On 21 June 2013 further dust emitted from dust
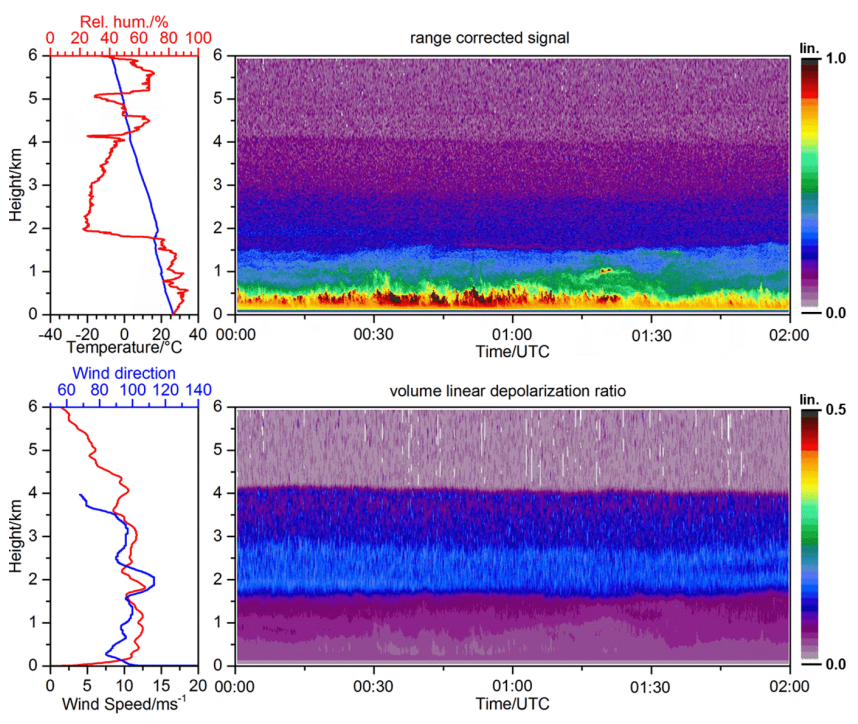

Figure 6. Same as Fig. 4 but for 27 June 2013, 00:00-02:00 UTC. The radiosonde was launched on 27 June at 00:24 UTC.

sources over the Adrar mountains (east Mali) and southeast Mauritania was contributing.

Figure 6 gives an overview of the nighttime measurement situation on 27 June 2013 over Barbados. The total AOD at $532 \mathrm{~nm}$ was as high as 0.4 . The range-corrected signal shows aerosol signatures up to about $4 \mathrm{~km}$, whereas the highest signals are observed in the lowermost aerosol layer up to about $0.6 \mathrm{~km}$. $\delta_{\mathrm{v}}$ shows high values of $\sim 0.15$ in the height range between 1.5 and $4 \mathrm{~km}$, clearly identifying the SAL. As observed during the case study of 20 June (23:30-24:00 UTC), the relative humidity in the SAL is low with values $<40 \%$ and the temperature profile shows a weak inversion at the lower edge of the SAL. The dusty air masses arrived from mainly easterly directions. Within the SAL, $\alpha_{\mathrm{p}}$ was about $0.08 \mathrm{~km}^{-1}$ and decreased at heights above $\approx 3.5 \mathrm{~km} . S_{\mathrm{p}}$ in the SAL shows mean values of $56 \pm 5 \mathrm{sr}$ at $532 \mathrm{~nm}$ and $55 \pm 7 \mathrm{sr}$ at $355 \mathrm{~nm}$, the corresponding $\delta_{\mathrm{p}}$ shows wavelengthindependent values of $0.26 \pm 0.01$ at $532 \mathrm{~nm}$ and $0.26 \pm 0.03$ at $355 \mathrm{~nm}$ (Fig. 7). Within the boundary layer, mean $S_{\mathrm{p}}$ values of $21 \pm 3 \mathrm{sr}$ at $532 \mathrm{~nm}$ and $17 \pm 2 \mathrm{sr}$ at $355 \mathrm{~nm}$ are observed. The mean $\delta_{\mathrm{p}}$ values in the boundary layer are $0.06 \pm 0.01$ at $532 \mathrm{~nm}$ and $0.04 \pm 0.01$ at $355 \mathrm{~nm}$.

\subsubsection{July 2013, 07:00-08:45 UTC}

On 1 July a total AOD of about 0.55 was observed over Barbados. Back trajectories show that Saharan air masses arriving Barbados on 1 July 2013 remained over West Africa for quite some time on 19 and 25 June before entering the tropical North Atlantic. During these days, frequently active dust source regions were located embedded in the desert valley of the Adra Mountains as well as in central Mali where sand sheets and ancient drainage systems characterize the 


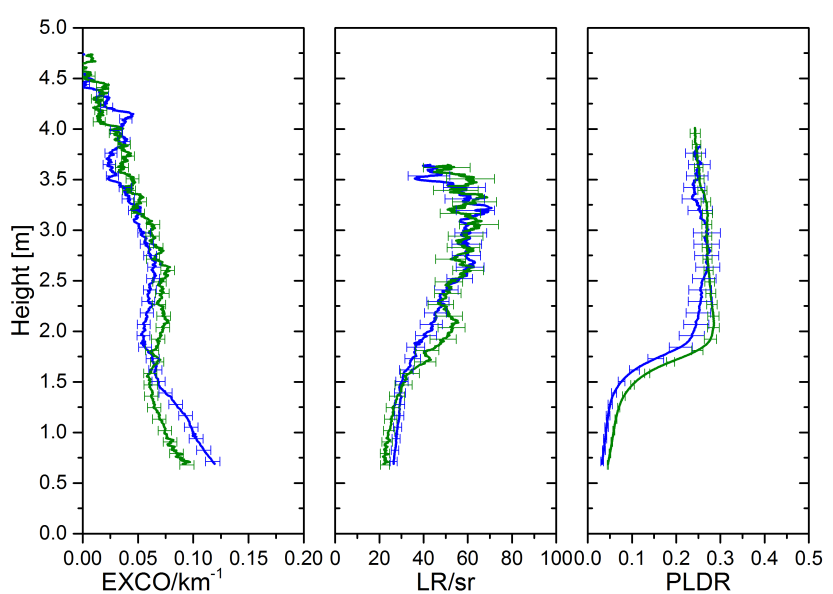

Figure 7. Same as Fig. 5 but for 27 June 2013, 00:00-02:00 UTC.
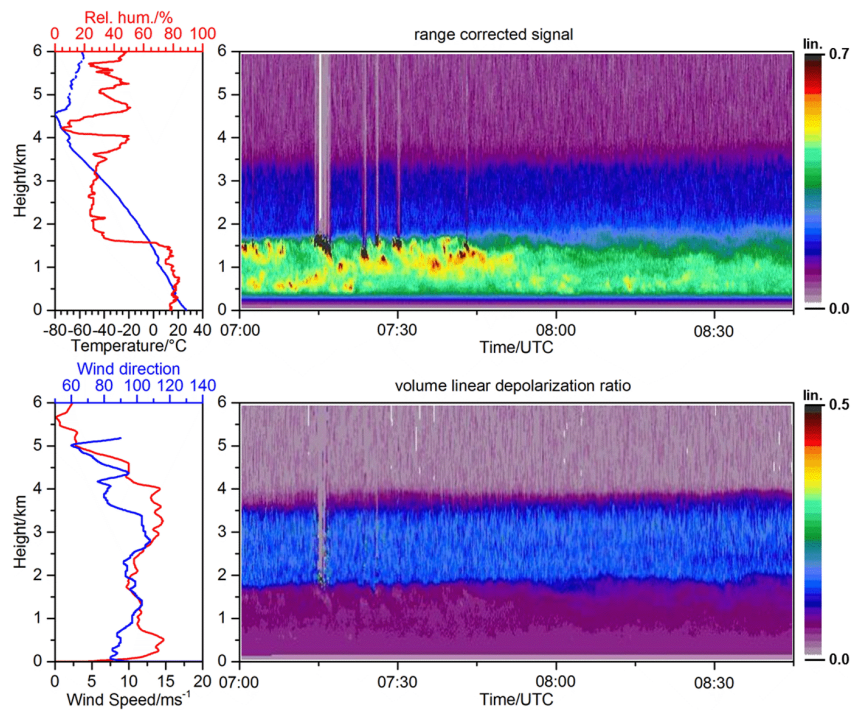

Figure 8. Same as Fig. 4 but for 1 July 2013, 07:00-08:45 UTC. The radiosonde was launched on 1 July at 00:00 UTC.

landscape. Dust sources were activated by both nocturnal LLJ embedded in the Harmattan flow resulting in a morning onset of dust emission and dust fronts (haboobs) related to downdrafts generated by MCSs (mesoscale convective systems) during the late afternoon and night.

The measurement situation on 1 July (07:00-09:45 UTC) was similar to those during the prior events (Fig. 8). Within the SAL, characterized by $\delta_{\mathrm{v}}$ values of about 0.15 , the relative humidity is $<40 \%$, whereas the boundary layer shows high $\mathrm{RH}$ values of up to $80 \%$. The wind direction within the aerosol layers was mainly easterly. Inside the $\operatorname{SAL} \alpha_{\mathrm{p}}$ values of about $0.75 \mathrm{~km}^{-1}$ are observed (Fig. 9). In the boundary layer, $\alpha_{\mathrm{p}}$ increases to values of about $0.13 \mathrm{~km}^{-1} . S_{\mathrm{p}}$ in the dust layer is wavelength independent with mean values of $54 \pm 7 \mathrm{sr}$ at $532 \mathrm{~nm}$ and $53 \pm 6 \mathrm{sr}$ at $355 \mathrm{~nm}$. $\delta_{\mathrm{p}}$ shows mean values of 0.27 at both wavelengths. In the boundary layer
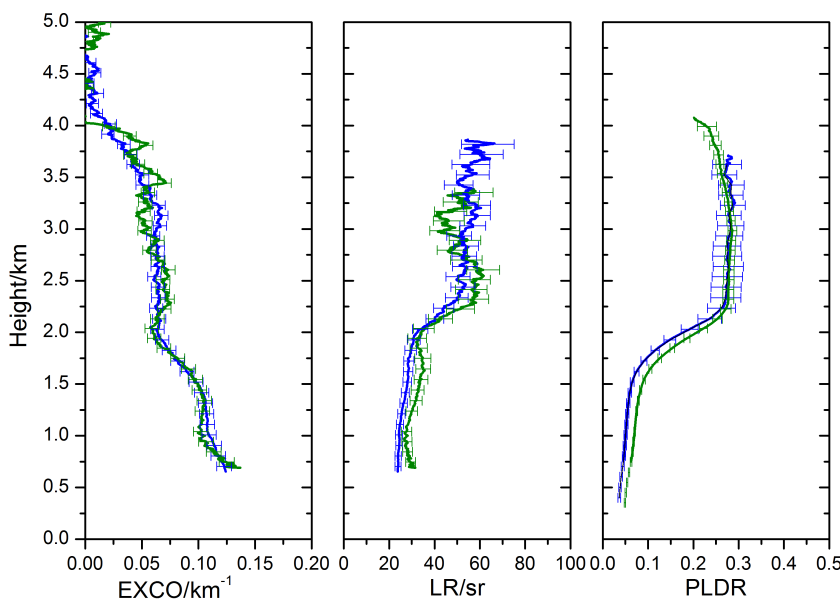

Figure 9. Same as Fig. 5 but for 1 July 2013, 07:00-08:45 UTC.

mean $S_{\mathrm{p}}$ values of $30 \pm 4 \mathrm{sr}$ at $532 \mathrm{~nm}$ and $25 \pm 2 \mathrm{sr}$ at $355 \mathrm{~nm}$ are found. Mean $\delta_{\mathrm{p}}$ values are $0.06 \pm 0.01$ at $532 \mathrm{~nm}$ and $0.04 \pm 0.01$ at $355 \mathrm{~nm}$.

\subsubsection{July 2013, 23:00-24:00 UTC}

The last dust event we observed during SALTRACE started after the passage of tropical storm "Chantal" on 9 July 2013 and lasted until the end of our measurements on 12 July 2013. Highest dust AOD up to 0.4 was observed on 11 July. Compared to the previous cases, the atmospheric humidity over North Africa has increased and deep convective clouds form in particular over orographic regions over the Sahara. The convective clouds grow to MCSs, which generate haboobs in particular over West Africa. Contributing dust originating from source over the southwest flanks of the Hoggar Massif were emitted by in the Harmattan flow embedded LLJs.

The top of the SAL observed over Barbados was at about $4.8 \mathrm{~km}$ height. Figure 10 gives an overview of the night measurements from 10 to 11 July (00:00-01:00 UTC). High intensity of the range-corrected signal was found in the boundary layer below about $0.5 \mathrm{~km}$. The lowest signal intensity was found above about $3.0 \mathrm{~km}$. However, $\delta_{\mathrm{v}}$ values of $0.15-0.18$ clearly identify the dust layer from 1.5 up to about $4.8 \mathrm{~km}$. The air masses arrived from northeasterly directions, and the SAL is characterized by very low wind speed (except for the uppermost $0.5 \mathrm{~km}$ ). Within the SAL the relative humidity shows again low values of $<40 \%$ while it jumps to values of about $80 \%$ in the boundary layer. $\alpha_{\mathrm{p}}$ is about 0.1 , wavelength independent in the SAL and shows even slightly higher values in the lowermost $1.5 \mathrm{~km}$ (Fig. 11). Mean $S_{\mathrm{p}}$ values of $56 \pm 4 \mathrm{sr}$ at $532 \mathrm{~nm}$ an $50 \pm 4 \mathrm{sr}$ at $355 \mathrm{~nm}$ are found in the SAL with wavelength-independent $\delta_{\mathrm{p}}$ of $0.27 \pm 0.01$ and $0.26 \pm 0.02$ at 532 and $355 \mathrm{~nm}$. In the boundary layer we find wavelength-independent mean $S_{\mathrm{p}}$ values of $35 \mathrm{sr}$ with corresponding $\delta_{\mathrm{p}}$ of $0.1 \pm 0.01$ at $532 \mathrm{~nm}$ and $0.14 \pm 0.01$ at 

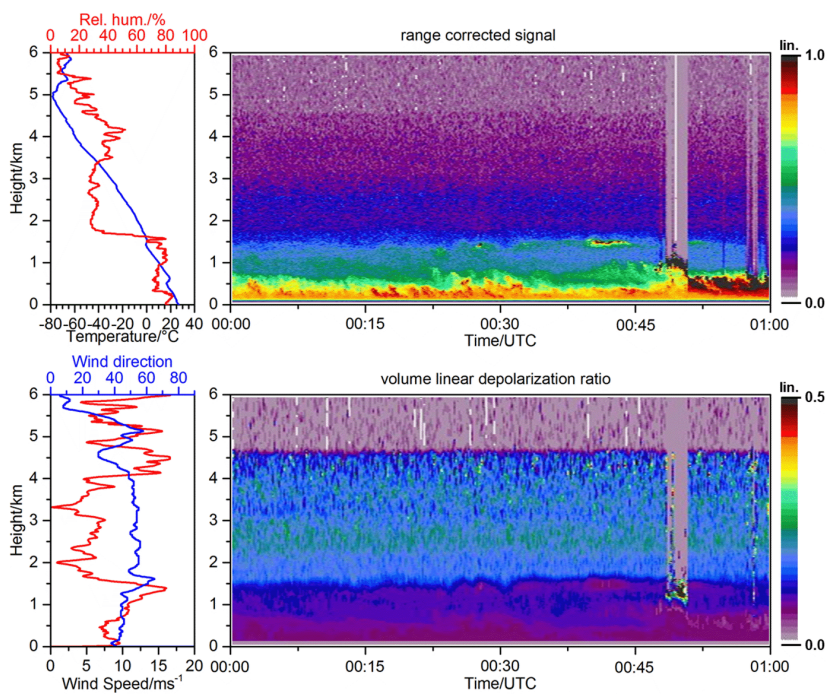

Figure 10. Same as Fig. 4 but for 11 July 2013, 23:00-24:00 UTC. The radiosonde was launched on 11 July at 23:26 UTC.

$355 \mathrm{~nm}$, indicating a certain amount of dust mixed into the boundary layer.

The main findings of the four case studies are summarized in Table 1.

\subsection{General findings}

The mean values of $S_{\mathrm{p}}$ and $\delta_{\mathrm{p}}$ within the SAL and within the boundary layer are shown in Fig. 13 and summarized in Table 2. The mean $S_{\mathrm{p}}$ values in the SAL range between 49 and $60 \mathrm{sr}$ at $532 \mathrm{~nm}$ and between 47 and $63 \mathrm{sr}$ at $355 \mathrm{~nm}$. The overall mean $S_{\mathrm{p}}$ values for long-range transported Saharan dust, considering all analyzed data, are $56 \pm 7 \mathrm{sr}$ and $53 \pm 5 \mathrm{sr}$ at 532 and $355 \mathrm{~nm}$. $\delta_{\mathrm{p}}$ values in the SAL range between 0.26 and 0.3 at $532 \mathrm{~nm}$ and between 0.24 and 0.29 at $355 \mathrm{~nm}$. The overall mean $\delta_{\mathrm{p}}$ values are of $0.27 \pm 0.01$ at $532 \mathrm{~nm}$ and $0.26 \pm 0.03$ at $355 \mathrm{~nm}$. However, during the first Saharan dust event $\delta_{\mathrm{p}}$ shows a slight but significant wavelength dependence with layer mean values of $\delta_{\mathrm{p}}=0.3 \pm 0.01$ at $532 \mathrm{~nm}$ and $\delta_{\mathrm{p}}=0.26 \pm 0.02$ at $355 \mathrm{~nm}$. Analysis of the remaining SALTRACE measurements show comparatively lower mean values at $532 \mathrm{~nm}$ with almost constant mean values at $355 \mathrm{~nm}$.

The boundary layer during SALTRACE was dominated by marine aerosols, with a contribution of various amounts of dust, especially during the last observed Saharan dust event. The mean $S_{\mathrm{p}}$ values range between 21 and $36 \mathrm{sr}$ at $532 \mathrm{~nm}$ and between 16 and $35 \mathrm{sr}$ at $355 \mathrm{~nm}$. The overall mean $S_{\mathrm{p}}$ shows a wavelength-independent value of $26 \mathrm{sr}$. Highest $S_{\mathrm{p}}$ values are found during the last observed dust event, indicating an increased amount of dust mixed into the boundary layer. This is in good agreement with the mean $\delta_{\mathrm{p}}$ values of $>0.1$ in the boundary layer during the last observed dust event, clearly identifying dust mixed in the boundary
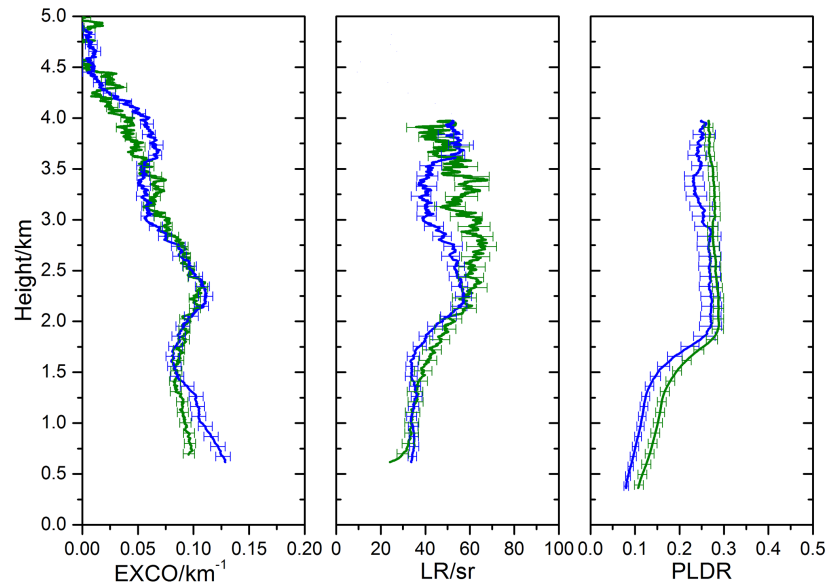

Figure 11. Same as Fig. 5 but for 11 July 2013, 23:00-24:00 UTC.

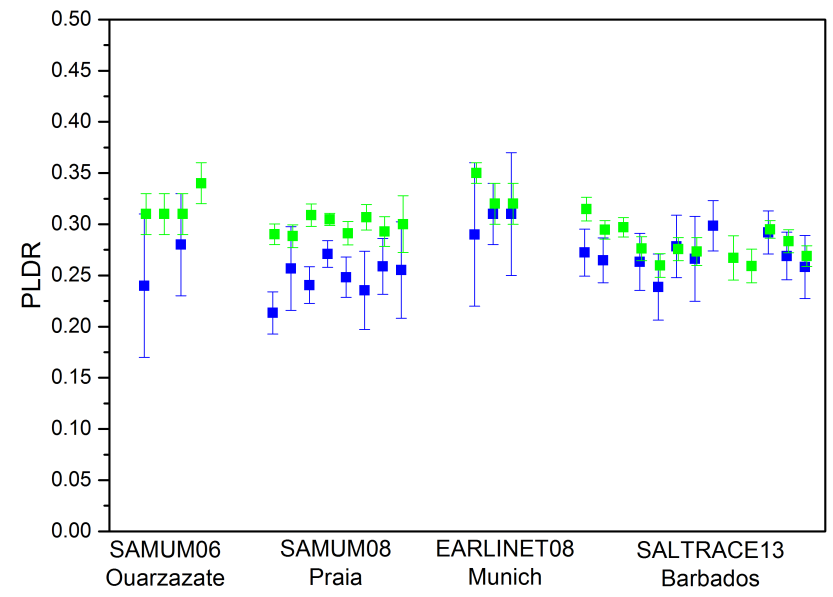

Figure 12. Mean values of the particle linear depolarization ratio of Saharan dust at $355 \mathrm{~nm}$ (blue) and $532 \mathrm{~nm}$ (green) derived for fresh Saharan dust on 4 days during SAMUM-1 in Ouarzazate, Morocco, in 2006 (SAMUM06) (Freudenthaler et al., 2009); for mid-range transported Saharan dust on 8 days during SAMUM-2 in Cape Verde in 2008 (SAMUM08) (Groß et al., 2011b); for longrange transported dust over Central Europe on 3 days in Munich, Germany, in 2008 (EARLINET08) (Wiegner et al., 2011); and for long-range transported Saharan dust over the Caribbean on 13 days during SALTRACE in Barbados in 2013 (SALTRACE13). The error bars denote the systematic errors.

layer (Tesche et al., 2009b; Groß et al., 2011a). During days when marine aerosols were the dominant type in the boundary layer, $\delta_{\mathrm{p}}$ is low with mean values between 0.01 and 0.04 at both wavelengths. The overall mean $\delta_{\mathrm{p}}$ values are $\delta_{\mathrm{p}}=0.05 \pm 0.01$ at $532 \mathrm{~nm}$ and $\delta_{\mathrm{p}}=0.04 \pm 0.01$ at $355 \mathrm{~nm}$. 
Table 1. Layer mean values for the case studies of lidar ratio $S_{\mathrm{p}}$ and particle linear depolarization ratio $\delta_{\mathrm{p}}$ including systematic errors $( \pm)$, the standard deviations of the values within the height range $(\sigma)$ indicating the variability of the values within the layer and the considered aerosol layer.

\begin{tabular}{|c|c|c|c|}
\hline Height/km a.g.l. & Lidar ratio/sr & PLDR & Layer \\
\hline \multicolumn{4}{|c|}{20 June $2013,23-23: 30$ UTC } \\
\hline $0.25^{\mathrm{b}} / 0.5^{\mathrm{a}}-1.5$ & $\begin{array}{l}21 \pm 3(\sigma=1)(532 \mathrm{~nm})^{\mathrm{a}} \\
17 \pm 2(\sigma=1)(355 \mathrm{~nm})^{\mathrm{a}}\end{array}$ & $\begin{array}{l}0.02 \pm 0.01(\sigma=0.01)(532 \mathrm{~nm})^{\mathrm{b}} \\
0.02 \pm 0.01(\sigma=0.01)(355 \mathrm{~nm})^{\mathrm{b}}\end{array}$ & Boundary layer \\
\hline $2.0-2.5$ & $\begin{array}{l}56 \pm 5(\sigma=2)(532 \mathrm{~nm}) \\
50 \pm 4(\sigma=2)(355 \mathrm{~nm})\end{array}$ & $\begin{array}{l}0.30 \pm 0.01(\sigma=0.01)(532 \mathrm{~nm}) \\
0.26 \pm 0.02(\sigma=0.01)(355 \mathrm{~nm})\end{array}$ & Dust layer \\
\hline \multicolumn{4}{|c|}{27 June 2013, 00:00-02:00 UTC } \\
\hline $0.25^{\mathrm{b}} / 0.5^{\mathrm{a}}-1.5$ & $\begin{array}{l}25 \pm 3(\sigma=1)(532 \mathrm{~nm})^{\mathrm{a}} \\
28 \pm 2(\sigma=1)(355 \mathrm{~nm})^{\mathrm{a}}\end{array}$ & $\begin{array}{l}0.06 \pm 0.01(\sigma=0.01)(532 \mathrm{~nm})^{b} \\
0.04 \pm 0.01(\sigma=0.01)(355 \mathrm{~nm})^{b}\end{array}$ & Boundary layer \\
\hline $2.0-3.5^{\mathrm{a}} / 3.75^{\mathrm{b}}$ & $\begin{array}{l}56 \pm 8(\sigma=5)(532 \mathrm{~nm})^{\mathrm{a}} \\
55 \pm 7(\sigma=7)(355 \mathrm{~nm})^{\mathrm{a}}\end{array}$ & $\begin{array}{l}0.26 \pm 0.01(\sigma=0.01)(532 \mathrm{~nm})^{b} \\
0.26 \pm 0.03(\sigma=0.01)(355 \mathrm{~nm})^{b}\end{array}$ & Dust layer \\
\hline \multicolumn{4}{|c|}{1 July 2013, 07:00-09:00 UTC } \\
\hline $0.4^{\mathrm{b}} / 0.5^{\mathrm{a}}-1.5$ & $\begin{array}{l}30 \pm 4(\sigma=2)(532 \mathrm{~nm})^{\mathrm{a}} \\
25 \pm 2(\sigma=1)(355 \mathrm{~nm})^{\mathrm{a}}\end{array}$ & $\begin{array}{l}0.06 \pm 0.01(\sigma=0.01)(532 \mathrm{~nm})^{\mathrm{b}} \\
0.04 \pm 0.01(\sigma=0.01)(355 \mathrm{~nm})^{\mathrm{b}}\end{array}$ & Boundary layer \\
\hline $2.25-3.5^{\mathrm{a}} / 3.75^{\mathrm{b}}$ & $\begin{array}{l}54 \pm 7(\sigma=8)(532 \mathrm{~nm})^{\mathrm{a}} \\
53 \pm 6(\sigma=3)(355 \mathrm{~nm})^{\mathrm{a}}\end{array}$ & $\begin{array}{l}0.27 \pm 0.01(\sigma=0.01)(532 \mathrm{~nm})^{\mathrm{b}} \\
0.27 \pm 0.03(\sigma=0.01)(355 \mathrm{~nm})^{\mathrm{a}}\end{array}$ & Dust layer \\
\hline \multicolumn{4}{|c|}{ 11 July 2013, 23:00-24:00 UTC } \\
\hline $0.4^{\mathrm{b}} / 0.75^{\mathrm{a}}-1.5$ & $\begin{array}{l}35 \pm 3(\sigma=2)(532 \mathrm{~nm})^{\mathrm{a}} \\
35 \pm 2(\sigma=1)(355 \mathrm{~nm})^{\mathrm{a}}\end{array}$ & $\begin{array}{l}0.10 \pm 0.01(\sigma=0.02)(532 \mathrm{~nm})^{\mathrm{b}} \\
0.14 \pm 0.01(\sigma=0.02)(355 \mathrm{~nm})^{\mathrm{b}}\end{array}$ & Boundary layer \\
\hline $2.0-4.0$ & $\begin{array}{l}56 \pm 7(\sigma=6)(532 \mathrm{~nm}) \\
50 \pm 4(\sigma=6)(355 \mathrm{~nm})\end{array}$ & $\begin{array}{l}0.27 \pm 0.01(\sigma=0.01)(532 \mathrm{~nm}) \\
0.26 \pm 0.02(\sigma=0.01)(355 \mathrm{~nm})\end{array}$ & Dust layer \\
\hline
\end{tabular}

$\mathrm{a}$ and ${ }^{\mathrm{b}}$ indicate the upper and/or lower boundary used to calculate the mean value.

\section{Discussion}

\subsection{Comparison to former dust measurements}

The lidar measurements performed in Barbados during SALTRACE and presented in this work give us the opportunity to compare the intensive lidar properties (e.g., the lidar ratio and the particle linear depolarization ratio) of Saharan dust derived close to the source region in Ouarzazate, Morocco, during SAMUM-1 (Freudenthaler et al., 2009) with measurements of mid-range transported Saharan dust in Cape Verde during SAMUM-2 (Groß et al., 2011b) and of long-range transported Saharan dust over the Atlantic Ocean. From these studies possible changes due to transport and aging can be studied. Comparisons with measurements of longrange transported Saharan dust over Central Europe (Wiegner et al., 2011) furthermore enable us to investigate whether not only the transport time but also the transport path has an effect of particle aging.

An overview of $\delta_{\mathrm{p}}$ measurements at 355 and $532 \mathrm{~nm}$ is given in Fig. 14. For each measurement campaign a num- ber of days $(4,8,3,13)$ is included in this study. The main findings are that $\delta_{\mathrm{p}}$ and its wavelength dependence do not change for measurements of fresh Saharan dust in Morocco, close to the source regions, and for dust mid-range transported over Cape Verde. The wavelength-dependent overall mean values are $0.31 \pm 0.01(532 \mathrm{~nm})$ and $0.25 \pm 0.07$ $(355 \mathrm{~nm})$ for fresh Saharan dust (Freudenthaler et al., 2009) and $0.3 \pm 0.01(532 \mathrm{~nm})$ and $0.25 \pm 0.03(355 \mathrm{~nm})$ for midrange transported Saharan dust (Groß et al., 2011b). For long-range transported Saharan dust towards Central Europe we found slightly higher values of $0.34 \pm 0.02$ and $0.30 \pm 0.05$ at 532 and $355 \mathrm{~nm}$, respectively (Wiegner et al., 2011). In Barbados we find a slightly lower mean $\delta_{\mathrm{p}}$ value of $0.27 \pm 0.01$ at $532 \mathrm{~nm}$ and a rather constant mean value of $0.26 \pm 0.03$ at $355 \mathrm{~nm}$. The observed differences between $\delta_{\mathrm{p}}$ for long-range transported dust compared to the values for pure and mid-range transported dust are small. However, we see different alterations of the optical properties of long-range transported Saharan dust towards Central Europe and of long-range transported Saharan dust over the Atlantic Ocean towards the Caribbean. We do not see a wavelength 


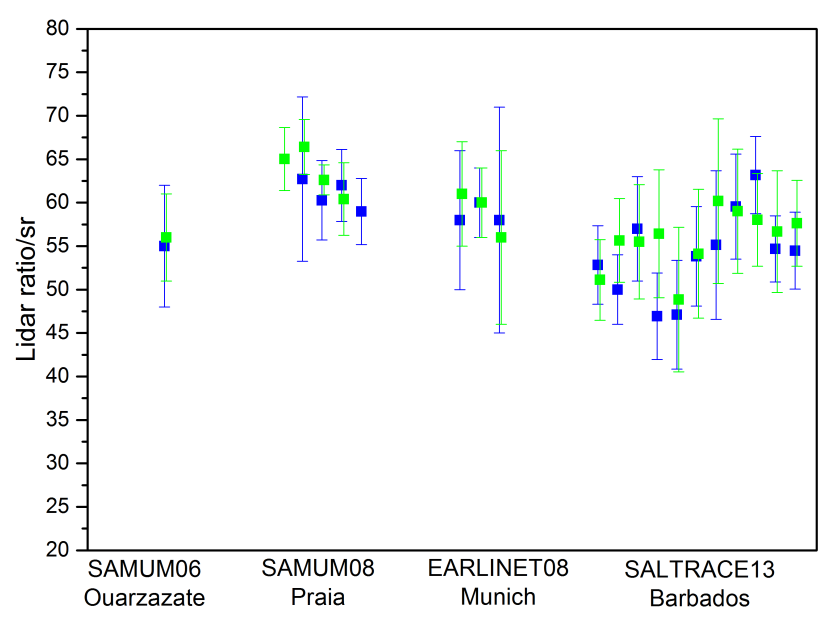

Figure 13. Mean values of the lidar ratio of Saharan dust at $355 \mathrm{~nm}$ (blue) and $532 \mathrm{~nm}$ (green) derived for fresh Saharan dust (mean campaign value) during SAMUM-1 in Ouarzazate, Morocco, in 2006 (SAMUM06) (Tesche et al., 2009b); for mid-range transported Saharan dust on 5 days during SAMUM-2 in Cape Verde in 2008 (SAMUM08) (Groß et al., 2011b); for long-range transported dust over Central Europe on 3 days in Munich, Germany, in 2008 (EARLINET08) (Wiegner et al., 2011); and for long-range transported Saharan dust over the Caribbean on 10 days during SALTRACE in Barbados in 2013 (SALTRACE13). The error bars denote the systematic errors.

dependence for $\delta_{\mathrm{p}}$ at 355 and $532 \mathrm{~nm}$ for long-range transported Saharan dust towards the Caribbean within the uncertainty range. Furthermore, the differences of $\delta_{\mathrm{p}}$ for longrange transported Saharan dust over Central Europe and over Barbados lead to the assumption that not only the time of long-range transport but also the transport path and the conditions during transport may be of importance when investigating the effects of aging and transport. These assumptions will be the subject of further studies.

A similar analysis was performed for $S_{\mathrm{p}}$ measurements during SAMUM-1 (mean value), SAMUM-2 (five cases), the Munich event in 2008 (three cases) and during the SALTRACE campaign (10 cases) (see Fig. 15). For the fresh Saharan dust in Ouarzazate wavelength-independent mean values of $S_{\mathrm{p}}=55 \pm 7 \mathrm{sr}$ at $355 \mathrm{~nm}$ and $S_{\mathrm{p}}=56 \pm 5 \mathrm{sr}$ at $532 \mathrm{~nm}$ were found (Tesche et al., 2009b). Slightly but not significantly higher lidar ratios were found during the $\mathrm{Mu}-$ nich dust event and the SAMUM-2 campaign for mid-range transported dust with wavelength-independent mean values of about $60 \mathrm{sr}$ (Wiegner et al., 2011; Groß et al., 2011b). These slightly higher values are in good agreement with the study of Schuster et al. (2012) investigating lidar ratios of mineral dust for different regions over northern Africa and finding the highest mean values for Saharan dust in Cape Verde. During SALTRACE the lidar ratios range between 47 and $63 \mathrm{sr}$ with mean values of $S_{\mathrm{p}}=56 \pm 7 \mathrm{sr}$ at $532 \mathrm{~nm}$ and $S_{\mathrm{p}}=53 \pm 5 \mathrm{sr}$ at $355 \mathrm{~nm}$. Altogether no significant changes
Table 2. Mean values and mean systematic errors of the lidar ratio and the linear particle depolarization ratio of Saharan dust at $355 \mathrm{~nm}$ and $532 \mathrm{~nm}$ derived for fresh Saharan dust during SAMUM-1 in Ouarzazate, Morocco, in 2006 (Tesche et al., 2009b); for mid-range transported Saharan dust during SAMUM-2 in Cape Verde in 2008 (Groß et al., 2011b); for long-range transported dust over Central Europe in Munich, Germany, in 2008 (Wiegner et al., 2011); and for long-range transported Saharan dust over the Caribbean during SALTRACE in Barbados in 2013.

\begin{tabular}{lrrr}
\hline Campaign & Lidar ratio/sr & PLDR & WL/nm \\
\hline \multirow{2}{*}{ SAMUM-1 } & $56 \pm 5$ & $0.31 \pm 0.01$ & 532 \\
& $55 \pm 7$ & $0.25 \pm 0.07$ & 355 \\
\hline \multirow{2}{*}{ SAMUM-2 } & $62 \pm 5$ & $0.30 \pm 0.01$ & 532 \\
& $58 \pm 7$ & $0.25 \pm 0.03$ & 355 \\
\hline \multirow{2}{*}{ Munich } & $59 \pm 7$ & $0.34 \pm 0.02$ & 532 \\
& $59 \pm 8$ & $0.30 \pm 0.05$ & 355 \\
\hline \multirow{2}{*}{ SALTRACE } & $56 \pm 7$ & $0.27 \pm 0.01$ & 532 \\
& $53 \pm 5$ & $0.26 \pm 0.03$ & 355 \\
\hline
\end{tabular}

in the lidar ratio can be found within the error bars for the fresh and the transported Saharan dust cases.

The mean values and mean uncertainties of $S_{\mathrm{p}}$ and $\delta_{\mathrm{p}}$ for the different dust measurements are summarized in Table 2.

\subsection{Impact on aerosol classification}

It has been shown that the lidar ratio and the particle linear depolarization ratio are quite different for different types of aerosol (Cattrall et al., 2005; Müller et al., 2007; Sakai et al., 2010; Burton et al., 2012). Therefore aerosol classification schemes at both 355 and $532 \mathrm{~nm}$ have been developed based on these intensive lidar optical properties (Groß et al., 2011b, 2013; Burton et al., 2012; Illingworth et al., 2015). Until now those classification schemes have not sufficiently accounted for the effect of aerosol aging on the thresholds for the discrimination of the different aerosol types. With our measurements during the SALTRACE campaign, in combination with the findings of former measurements of fresh and mid-range transported dust during the SAMUM project and long-range transported dust measurements over Central Europe, we are now able to investigate the effect of transport and aging on the lidar optical properties of Saharan dust.

Figure 14 shows the particle linear depolarization ratio versus the lidar ratio at 355 and $532 \mathrm{~nm}$ of the different aerosol types which are, until now, included in the aerosol classification schemes for EarthCARE (Illingworth et al., 2015; Groß et al., 2015). Additionally we plotted our results found during the SALTRACE campaign for pure Saharan dust and for the boundary layer. Within the boundary layer our results fit quite well with former results found for marine aerosols or marine aerosol mixtures, indicating that the boundary layer was dominated by marine aerosols 

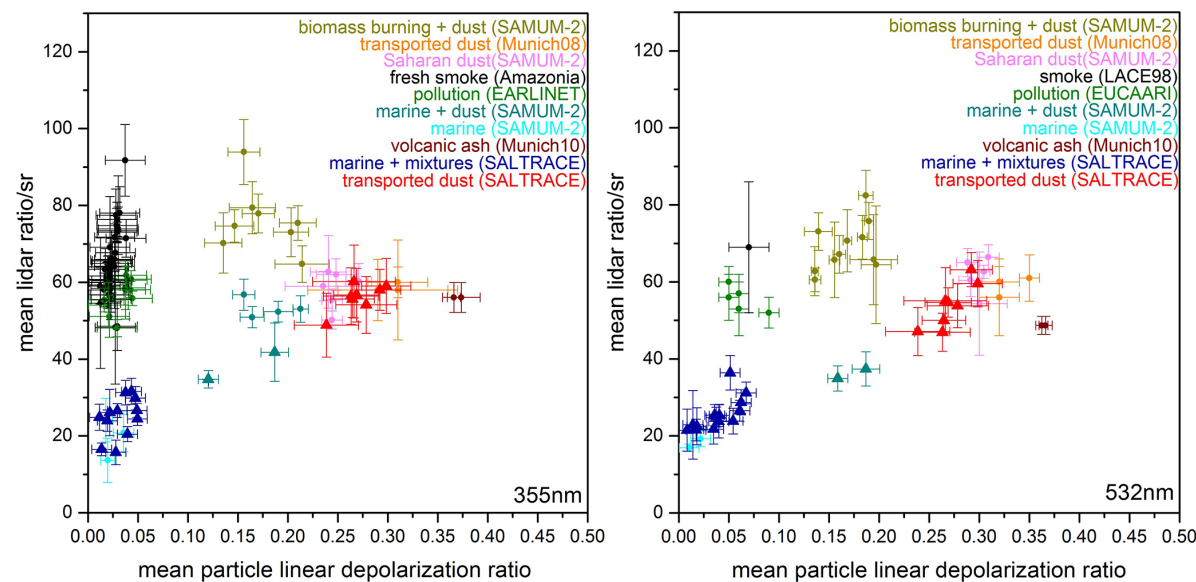

Figure 14. Aerosol classification at $355 \mathrm{~nm}$ (left) and $532 \mathrm{~nm}$ (right) based on the lidar ratio and the particle linear depolarization ratio. Measurements at $355 \mathrm{~nm}$ were performed with the ground-based Raman polarization lidars POLIS (Ludwig-Maximilians-Universität München) and with PollyXT of the Leibniz Institute for Tropospheric Research. Measurements were conducted during SAMUM-2 in Cape Verde (Saharan dust, marine, marine and dust and biomass burning and dust; Groß et al., 2011b), in the framework of EARLINET in Leipzig, Germany (pollution; Illingworth et al., 2015), and in Munich, Germany (volcanic ash, transported dust; Groß et al., 2012; Wiegner et al., 2011), and in the Amazon Basin (fresh smoke; Baars et al., 2012).

with various amount of dust mixed into the boundary layer on specific days. Regarding the Saharan dust layer one can see that the $\delta_{\mathrm{p}}-S_{\mathrm{p}}$ space at $355 \mathrm{~nm}$ shows a good agreement with former dust measurements during SAMUM. The specified threshold of $0.23 \leq \delta_{\mathrm{p}} \leq 0.33$ to identify pure Saharan dust from combined $\delta_{\mathrm{p}}-S_{\mathrm{p}}$ measurements (Groß et al., 2015) is still valuable for long-range transported dust. At $532 \mathrm{~nm}$ the SALTRACE results for long-range transported Saharan dust show slightly lower $\delta_{\mathrm{p}}$ values compared to the threshold $\left(\delta_{\mathrm{p}} \geq 0.28\right)$ used for the identification of Saharan dust (Groß et al., 2015). Thus this threshold has to be adapted to a slightly lower $\delta_{\mathrm{p}}$ value of 0.26 to consider long-range transported Saharan dust.

\section{Conclusions}

We presented optical properties of Saharan dust long-range transported across the Atlantic Ocean to Barbados. For this purpose we analyzed measurements with the lidar system POLIS at 355 and $532 \mathrm{~nm}$; in particular we calculated the extinction coefficient $\alpha_{\mathrm{p}}$, the lidar ratio $S_{\mathrm{p}}$ and the particle linear depolarization ratio $\delta_{\mathrm{p}}$. While the first properties give us information about the aerosol load, the latter two properties are intensive lidar properties and thus only dependent on the aerosol type and not on its amount. Therefore, these properties are used for aerosol classification schemes based on lidar measurements (Burton et al., 2012; Groß et al., 2013, 2015; Illingworth et al., 2015). The measurements and results of this work follow up former measurements performed during the SAMUM-1 (Freudenthaler et al., 2009; Tesche et al., 2009b) and SAMUM-2 (Groß et al., 2011b; Tesche et al., 2011) campaigns and during a strong Saharan dust event over
Central Europe observed in the framework of EARLINET (Wiegner et al., 2011). Thus, we are able to study possible changes of the optical properties of Saharan dust caused by long-range transport.

For the long-range transported Saharan dust over Barbados we found typical values of $\delta_{\mathrm{p}}$ between 0.26 and 0.3 at $532 \mathrm{~nm}$ and between 0.24 and 0.29 at $355 \mathrm{~nm}$. The mean systematic errors are 0.01 and 0.03 at 532 an $355 \mathrm{~nm}$, respectively. Compared to $\delta_{\mathrm{p}}$ measurements at $532 \mathrm{~nm}$ during the SAMUM campaigns we see slightly lower values for longrange transported Saharan dust to Barbados, while over Central Europe slightly higher values have been found. This leads to the assumption that not only transport time but also the transport path and the transport conditions have an influence on possible changes of the optical properties of Saharan dust. At $355 \mathrm{~nm}$ we do not see significant changes in the $\delta_{\mathrm{p}}$ values although the overall mean values are slightly higher for long-range transported Saharan dust to Barbados as well as to Central Europe. For long-range transported Saharan dust we do not see a significant wavelength dependence anymore.

Mean values of the lidar ratio of the long-range transported Saharan dust over Barbados are $56 \pm 7 \mathrm{sr}$ at $532 \mathrm{~nm}$ and $53 \pm 5 \mathrm{sr}$ and thus agree well with the values found for fresh Saharan dust over Morocco (Tesche et al., 2009b). Although these values are slightly lower than the values found for long-range transported Saharan dust over Central Europe (Wiegner et al., 2011) and of mid-range transported Saharan dust over Cape Verde (Groß et al., 2011b), they agree for the measurement uncertainties. Thus we do not see a significant change in these optical properties during transport.

Though the presented measurements are a good test bed to study the optical properties of long-range transported 
Saharan dust, there are a number of questions remaining unsolved, e.g., the impact of transport condition on the changes of optical and microphysical properties. Thus further studies will combine lidar measurements with information of the transport conditions and path, e.g., from model calculations. Furthermore, lidar measurements will be combined with in situ measurements to investigate the relationship between optical and microphysical properties, e.g., the cloud condensation properties, and a possible vertical sorting within the dust layer as recently suggested by Yang et al. (2013).

Acknowledgements. This work has been partly funded by the Deutsche Forschungsgemeinschaft (DFG) in the SPP (no. 1294/2) "Atmosphären- und Erdsystemforschung mit dem Forschungsflugzeug HALO (High Altitude and Long Range Research Aircraft)" under contract no. KI1567/1-1 and by the Helmholtz Association under grant no. VH-NG-606 (Helmholtz-HochschulNachwuchsforschergruppe AerCARE). The SALTRACE campaign was mainly funded by the Helmholtz Association, the Deutsches Zentrum für Luft- und Raumfahrt (DLR), the Ludwig-MaximiliansUniversität München (LMU) and the Institut für Troposphärenforschung (TROPOS). CIMEL calibration was performed at the AERONET-EUROPE calibration center at GOA-UVA, supported by ACTRIS (European Union Seventh Framework Program, FP7/2007-2013) under grant agreement no. 262254. The lidar and sun-photometer measurements were performed at the site of the Caribbean Institute for Meteorology and Hydrology (CIMH). We thank CIMH for providing us with this measurement environment.

The article processing charges for this open-access publication were covered by a Research

Centre of the Helmholtz Association.

Edited by: C. Flamant

\section{References}

Amiridis, V., Balis, D. S., Giannakaki, E., Stohl, A., Kazadzis, S., Koukouli, M. E., and Zanis, P.: Optical characteristics of biomass burning aerosols over Southeastern Europe determined from UVRaman lidar measurements, Atmos. Chem. Phys., 9, 2431-2440, doi:10.5194/acp-9-2431-2009, 2009.

Ansmann, A., Riebensell, M., and Weitkamp, C.: Measurement of atmospheric aerosol extinction profiles with a Raman lidar, Opt. Lett., 14, 746-748, 1990.

Ansmann, A., Wandinger, U., Riebesell, M., Weitkamp, C., and Michaelis, W.: Independent measurement of extinction and backscatter profiles in cirrus clouds by using a combined Raman elastic-backscatter lidar, Appl. Optics, 31, 7113-7113, doi:10.1364/AO.31.007113, 1992.

Ansmann, A., Petzold, A., Kandler, K., Tegen, I., Manfred, W., Müller, D., Weinzierl, B., Müller, T., and Heintzenberg, J.: Saharan Mineral Dust Experiments SAMUM-1 and SAMUM-2: what have we learned?, Tellus B, 63, 403-429, doi:10.1111/j.16000889.2011.00555.x, 2011.

Baars, H., Ansmann, A., Althausen, D., Engelmann, R., Heese, B., Müller, D., Artaxo, P., Paixao, M., Pauliquevis, T., and Souza,
R.: Aerosol profiling with lidar in the Amazon Basin during the wet and dry season, J. Geophys. Res.-Atmos., 117, D21201, doi:10.1029/2012JD018338, 2012.

Bauer, S. E., Mishchenko, M. I., Lacis, A. A., Zhang, S., Perlwitz, J., and Metzger, S. M.: Do sulfate and nitrate coatings on mineral dust have important effects on radiative properties and climate modeling?, J. Geophys. Res.-Atmos., 112, D06307, doi:10.1029/2005JD006977, 2007.

Biele, J., Beyerle, G., and Baumgarten, G.: Polarization Lidar: Correction of instrumental effects, Opt. Express, 7, 427-435, doi:10.1364/OE.7.000427, 2000.

Boucher, O., Randall, D., Artaxo, P., Bretherton, C., Feingold, G., Forster, P., Keminen, V.-M., Kondo, Y., Liao, H., Lohmann, U., Rasch, P., Satheesh, S., Sherwood, S., Stevens, B., and Zhang, X. Y.: Clouds and Aerosols, in: Climate Change 2013: The Physical Science Basis. Contribution of Working Group I to the Fifth Assessment Report of the Intergovernmental Panel on Climate Change, Cambridge University Press, 571-657, 2013.

Burton, S. P., Ferrare, R. A., Hostetler, C. A., Hair, J. W., Rogers, R. R., Obland, M. D., Butler, C. F., Cook, A. L., Harper, D. B., and Froyd, K. D.: Aerosol classification using airborne High Spectral Resolution Lidar measurements - methodology and examples, Atmos. Meas. Tech., 5, 73-98, doi:10.5194/amt-5-73-2012, 2012.

Cattrall, C., Reagan, J., Thome, K., and Dubovik, O.: Variability of aerosol and spectral lidar and backscatter and extinction ratios of key aerosol types derived from selected Aerosol Robotic Network locations, J. Geophys. Res., 110, D10S11, doi:10.1029/2004JD005124, 2005.

Draxler, R. R. and Rolph, G. D.: HYSPLIT (HYbrid Single Particle Lagrangian Integrated Trajectory) Model, NOAA Air Resources Laboratory, Silver Spring, MD, available at: http://ready.arl.noaa. gov/HYSPLIT.php (last access: 31 October 2014), 2012.

Forster, P., Ramaswamy, V., Artaxo, P., Berntsen, T., Betts, R., Fahey, D. W., Haywood, J., Lean, J., Lowe, D. C., Myhre, G. Nganga, J., Prinn, R., Raga, G., Schulz, M., and Van Dorland, R.: Changes in atmospheric constituents and in radiative forcing, Climate Change 2007: The Physical Science Basis. Contribution of Working Group I to the Fourth Assessment Report of the Intergovernmental Panel on Climate Change, Cambridge University Press, 210-215, 2007.

Freudenthaler, V., Esselborn, M., Wiegner, M., Heese, B., Tesche, M., Ansmann, A., Müller, D., Althause, D., Wirth, M., Fix, A., Ehret, G., Knippertz, P., Toledano, C., Gasteiger, J., Garhammer, M., and Seefeldner, M.: Depolarization ratio profiling at several wavelengths in pure Saharan dust during SAMUM 2006, Tellus B, 61, 165-179, 2009.

Freudenthaler, V., Seefeldner, M., Groß, S., and Wandinger, U.: Accuracy of linear depolarisation ratios in clean air ranges measured with POLIS-6 at 355 and $532 \mathrm{~nm}$, Proceeding of 27, International Laser Radar Conference, New York, 2015.

Gasteiger, J., Groß, S., Freudenthaler, V., and Wiegner, M.: Volcanic ash from Iceland over Munich: mass concentration retrieved from ground-based remote sensing measurements, Atmos. Chem. Phys., 11, 2209-2223, doi:10.5194/acp-11-22092011, 2011a.

Gasteiger, J., Wiegner, M., Groß, S., Freudenthaler, V., Toledano, C., Tesche, M., and Kandler, K.: Modeling lidar-relevant optical 
properties of complex mineral dust aerosols, Tellus B, 63, 725741, doi:10.1111/j.1600-0889.2011.00559.x, 2011b.

Goudie, A. and Middleton, N.: Saharan dust storms: nature and consequences, Earth-Sci. Rev., 56, 179-204, 2001.

Groß, S., Freudenthaler, V., Wirth, M., and Weinzierl, B.: Towards an aerosol classification scheme for future EarthCARE lidar observations and implications for research needs, Atmos. Sci. Lett., 16, 77-82, doi:10.1002/asl2.524, 2015.

Groß, S., Gasteiger, J., Freudenthaler, V., Wiegner, M., Geiß, A., Toledano, C., Kandler, K., Tesche, M., Ansmann, A., and Wiedensohler, A.: Characterization of the planetary boundary layer during SAMUM-2 by means of lidar measurements, Tellus B, 63, 695-705, 2011a.

Groß, S., Tesche, M., Freudenthaler, V., Toledano, C., Wiegner, M., Ansmann, A., Althausen, D., and Seefeldner, M.: Characterization of Saharan dust, marine aerosols and mixtures of biomass burning aerosols and dust by means of multi-wavelength depolarization- and Raman-measurments during SAMUM-2, Tellus B, 63, 706-724, doi:10.1111/j.1600-0889.2011.00556.x, 2011b.

Groß, S., Wiegner, M., Freudenthaler, V., and Toledano, C.: Lidar ratio of Saharan dust over Cape Verde Islands: Assessment and error calculation, J. Geophys. Res.-Atmos., 116, D15203, doi:10.1029/2010JD015435, 2011c.

Groß, S., Freudenthaler, V., Wiegner, M., Gasteiger, J., Geiß, A., and Schnell, F.: Dual-wavelength linear depolarization ratio of volcanic aerosols: Lidar measurements of the Eyjafjallajökull plume over Maisach, Germany, Atmos. Environ., 48, 85-96, 2012

Groß, S., Esselborn, M., Weinzierl, B., Wirth, M., Fix, A., and Petzold, A.: Aerosol classification by airborne high spectral resolution lidar observations, Atmos. Chem. Phys., 13, 2487-2505, doi:10.5194/acp-13-2487-2013, 2013.

Groß, S., Wirth, M., Schäfler, A., Fix, A., Kaufmann, S., and Voigt, C.: Potential of airborne lidar measurements for cirrus cloud studies, Atmos. Meas. Tech., 7, 2745-2755, doi:10.5194/amt-72745-2014, 2014.

Hand, V. L., Capes, G., Vaughn, D. J., Formenti, P., Haywood, J. M., and Coe, H.: Evidence of internal mixing of African dust and biomass burning particles by individual particle analysis using electron beam techniques, J. Geophys. Res.-Atmos., 38, $513-$ $543,2000$.

Haywood, J. and Boucher, O.: Estimates of the direct and indirect radiative forcing due to tropospheric aerosols: a review, Rev. Geophys., 38, 513-543, 2000.

Holben, B., Eck, T., Slutsker, I., Tanré, D., Buis, J., Setzer, A., Vermote, E., Reagan, J., Kaufman, Y., Nakajima, T., Lavenu, F., Jankowiak, I., and Smirnov, A.: AERONET - A Federated Instrument Network and Data Archive for Aerosol Characterization, Remote Sens. Environ., 66, 1-16, doi:10.1016/S00344257(98)00031-5, 1998.

Illingworth, A. J., Barker, H. W., Beljaars, A., Ceccaldi, M., Chepfer, H., Cole, J., Delanoë, J., Domenech, C., Donovan, D. P., Fukuda, S., Hirakata, M., Hogan, R. J., Huenerbein, A., Kollias, P., Kubota, T., Nakajima, T., Nakajima, T. Y., Nishizawa, T., Ohno, Y., Okamoto, H., Oki, R., Sato, K., Satoh, M., Shephard, M., Wandinger, U., Wehr, T., and van Zadelhoff, G.-J.: THE EARTHCARE SATELLITE: The next step forward in global measurements of clouds, aerosols, precipitation and radiation, B.
Am. Meteorol. Soc., 96, 1311-1332, doi:10.1175/BAMS-D-12$00227.1,2015$.

IPCC: Climate Change 2013: The Scientific Basis, Cambridge University Press, 2013.

Liu, Z., Omar, A., Vaughan, M., Hair, J., Kittaka, C., Hu, Y., Powell, K., Trepte, C., Winker, D., Hostetler, C., Ferrare, R., and Pierce, R.: Calipso lidar observations of the optical properties of saharan dust: A case study of long-range transport, J. Geophys. Res., 113, D07207, doi:10.1029/2007JD008878, 2008.

Müller, D., Ansmann, A., Mattis, I., Tesche, M., Wandinger, U., Althausen, D., and Pisani, G.: Aerosol-type-dependent lidar ratios observed with Raman lidar, J. Geophys. Res., 112, D16202, doi:10.1029/2006JD008292, 2007.

Nousiainen, T.: Optical modeling of mineral dust particles: A review, J. Quant. Spectrosc. Ra., 110, 1261-1279, doi:10.1016/j.jqsrt.2009.03.002, 2009.

Omar, A., Winker, D., Kittaka, C., Vaughan, M., Liu, Z., Hu, Y., Trepte, C., Rogers, R., Ferrare, R., Lee, K., Kuehn, R., and Hostetler, C.: The CALIPSO Automated Aerosol Classification and Lidar Ratio Selection Algorithm, J. Atmos. Ocean. Tech., 26, 1994-2014, 2009.

Penner, J. E., Andreae, M., Annegarn, H., Barrie, L., Feichter, J., Hegg, D., Jayaraman, A., Leaitch, R., Murphy, D., Nganga, J., Pitari, G., Ackerman, A., Adams, P., Austin, P., Boers, R., Boucher, O., Chin, M., Chuang, C., Collins, B., Cooke, W., DeMott, P., Feng, Y., Fischer, H., Fung, I., Ghan, S., Ginoux, P., Gong, S.-L., Guenther, A., Herzog, M., Higurashi, A., Kaufman, Y., Kettle, A., Kiehl, J., Koch, D., Lammel, G., Land, C., Lohmann, U., Madronich, S., Mancini, E., Mishchenko, M., Nakajima, T., Quinn, P., Rasch, P., Roberts, D. L., Savoie, D., Schwartz, S., Seinfeld, J., Soden, B., Tanré, D., Taylor, K., Tegen, I., Tie, X., Vali, G., Van Dingenen, R., van Weele, M., and Zhang, Y.: Climate change 2001: The scientific assessment, Cambridge Univ. Press, 289-348, 2001.

Penner, J. E., Xu, L., and Wang, M.: Satellite methods underestimate indirect climate forcing by aerosols, P. Natl. Acad. Sci., 108, 13404-13408, 2011.

Piironen, P. and Eloranta, E. W.: Demonstration of a high-spectralresolution lidar based on an iodine absorption filter, Opt. Lett., 19, 234-236, doi:10.1364/OL.19.000234, 1994.

Prospero, J. M., Bonatti, E., Schubert, C., and Carlson, T. N.: Dust in the Caribbean atmosphere traced to an African dust storm, Earth Planet. Sc. Lett., 9, 287-293, doi:10.1016/0012821X(70)90039-7, 1970

Redmond, H. E., Dial, K. D., and Thompson, J. E.: Light scattering and absorption by wind blown dust: Theory, measurement, and recent data, Aeolian Research, 2, 5-26, doi:10.1016/j.aeolia.2009.09.002, 2010.

Sakai, T., Nagai, T., Zaizen, Y., and Mano, Y.: Backscattering linear depolarization ratio measurements of mineral, sea-salt, and ammonium sulfate particles simulated in a laboratory chamber, Appl. Optics, 49, 4441-4449, doi:10.1364/AO.49.004441, 2010.

Sassen, K., Zhao, H., and Yu, B.-K.: Backscatter laser depolarization studies of simulated stratospheric aerosols: crystallized sulfuric acid droplets, Appl. Optics, 28, 3024-3029, doi:10.1364/AO.28.003024, 1989.

Schepanski, K., Tegen, I., Laurent, B., Heinold, B., and Macke, A.: A new Saharan dust source activation frequency map de- 
rived from MSG-SEVIRI IR-channels, Geophys. Res. Lett., 34, L18803, doi:10.1029/2007GL030168, 2007.

Schuster, G. L., Vaughan, M., MacDonnell, D., Su, W., Winker, D., Dubovik, O., Lapyonok, T., and Trepte, C.: Comparison of CALIPSO aerosol optical depth retrievals to AERONET measurements, and a climatology for the lidar ratio of dust, Atmos. Chem. Phys., 12, 7431-7452, doi:10.5194/acp-12-7431-2012, 2012.

Shao, Y., Wyrwoll, K.-H., Chappell, A., Huang, J., Lin, Z., McTainsh, G. H., Mikami, M., Tanaka, T. Y., Wang, X., and Yoon, S.: Dust cycle: An emerging core theme in Earth system science, Aeolian Research, 2, 181-204, doi:10.1016/j.aeolia.2011.02.001, 2011.

Shimizu, A., Sugimoto, N., Matsui, I., Arao, K., Uno, I., Murayama, T., Kagawa, N., Aoki, K., Uchiyama, A., and Yamazaki, A.: Continuous observations of Asian dust and other aerosols by polarization lidar in China and Japan during ACE-Asia, J. Geophys. Res., 109, D19S17, doi:10.1029/2002JD003253, 2004.

Shimizu, H., Lee, S., and She, C.: High spectral resolution lidar system with atomic blocking filters for measuring atmospheric parameters, Appl. Optics, 22, 1373-1381, doi:10.1364/AO.22.001373, 1983.

Shipley, S., Tracy, D., Eloranta, E., Trauger, J., Sroga, J., Roesler, F., and Weinman, J.: High spectral resolution lidar to measure optical scattering properties of atmospheric aerosols. 1: Theory and instrumentation, Appl. Optics, 22, 3716-3724, doi:10.1364/AO.22.003716, 1983.

Su, W., Loeb, N. G., Schuster, G. L., Chin, M., and Rose, F. G.: Global all-sky shortwave direct radiative forcing of anthropogenic aerosols from combined satellite observations and GOCART simulations, J. Geophys. Res.-Atmos/, 118, 655-669, doi:10.1029/2012JD018294, 2013.

Tesche, M., Ansmann, A., Müller, D., Althausen, D., Engelmann, R., Freudenthaler, V., and Groß, S.: Vertically resolved separation of dust and smoke over Cape Verde using multiwavelength Raman and polarization lidars during Saharan Mineral Dust Experiment 2008, J. Geophys. Res., 114, D13202, doi:10.1029/2009JD011862, 2009a.
Tesche, M., Ansmann, A., Müller, D., Althausen, D., Mattis, I., Heese, B., Freudenthaler, V., Wiegner, M., Esselborn, M., Pisani, G., and Knippertz, P.: Vertical profiling of Saharan dust with Raman lidars and airborne HSRL in southern Morocco during SAMUM, Tellus B, 61, 144-164, 2009b.

Tesche, M., Gross, S., Ansmann, A., Müller, D., Althause, D., Freudenthaler, V., and Esselborn, M.: Profiling of Saharan dust and biomass-burning smoke with multiwavelength polarization Raman lidar at Cape Verde, Tellus B, 63, 649-676, doi:10.1111/j.1600-0889.2011.00548.x, 2011.

Washington, R., Todd, M., Middleton, N. J., and Goudie, A. S.: Dust-Storm Source Areas Determined by the Total Ozone Monitoring Spectrometer and Surface Observations, Ann. Assoc. Am. Geogr., 93, 297-313, 2003.

Weinzierl, B., Sauer, D., Esselborn, M., Petzold, A., Mund, S., Veira, A., Tesche, M., Ansmann, A., and Wirth, M.: Airborne observations of microphysical and optical properties of dust and biomass burning aerosol layers in the Cape Verde region during SAMUM 2008, Tellus B, 63, 589-618, doi:10.1111/j.16000889.2011.00566.x, 2011.

Wiegner, M., Groß, S., Freudenthaler, V., Schnell, F., and Gasteiger, J.: The May/June 2008 Saharan dust event over Munich: Intensive aerosol parameters from lidar measurements, J. Geophys. Res.-Atmos., 116, 1984-2012, 2011.

Winker, D. M., Vaughan, M. A., Omar, A., Hu, X., Powell, K. A., Liu, Z., Hund, W. H., and Young, S. A.: Overview of the CALIPSO Mission and CALIOP Data Processing Algorithms, J. Atmos. Ocean. Tech., 26, 2310-2323, doi:10.1175/2009JTECHA1281.1, 2009.

Yang, W., Marshak, A., Kostinski, A. B., and Várnai, T.: Shape-induced gravitational sorting of Saharan dust during transatlantic voyage: Evidence from CALIOP lidar depolarization measurements, Geophys. Res. Lett., 40, 3281-3286, doi:10.1002/grl.50603, 2013. 